\title{
Knowledge, attitude, and practice toward COVID-19 among Iraqi people: a web-based cross-sectional study
}

\author{
Saad Ahmed Ali Jadoo ${ }^{1 *}$, Adil Hassan Alhusseiny², Shukur Mahmood Yaseen ${ }^{3}$, Mustafa Ali Mustafa \\ Al-Samarrai ${ }^{4}$, Ru'ya Abdulhadi Al-Rawi ${ }^{4}$, Ahmed K. Al-Delaimy ${ }^{4}$, Mohammed Waheeb Abed ${ }^{5}$, Hanan \\ Raheem Hassooni ${ }^{6}$
}

\begin{abstract}
Background: Iraq was among the first countries invaded by the novel human coronavirus (SARS-COV-2) after China. This study aimed to assess the Iraqi people's knowledge, attitudes, and practices toward COVID-19 during the pandemic.

Methods: A cross-sectional study recruiting an online self-reported survey conducted from 17-31 July 2020. Data of 877 participants have undergone descriptive, univariate, and multivariable regression analyses, respectively, to assess the differences in mean scores and identify factors associated with knowledge, attitudes, and practices (KAP) toward COVID-19.

Results: Most of the respondents (78.8\%) from the urban region, highly educated (69.7\%), aged less than 45 years $(61.2 \%)$, females $(58.3 \%)$, married $(51.9 \%)$, and $74.0 \%$ self-ranked health as good. Less than half $(45.4 \%)$ were employed; however, the average monthly income was USD 400 or more in about $66.8 \%$ of them. The mean knowledge, attitude and practice score was $15.57 \pm 2.46$ (range: $0-20), 38.88$ (SD = 3.57, (range: $11-55)$, and 5.13 (SD $=1.14$, range: $0-6)$, respectively. Findings of regression analysis showed that higher educated $(p<0.001)$, urban residents $(P<0.001)$, employed $(P=0.040)$, and having an income level of USD 400 or more $(P<0.001)$ were significantly associated with upper knowledge score. Female gender and employed respondents are significantly associated with positive attitude scores, but inversely respondents with an income of USD 400 or more are significantly associated with a negative attitude. Regarding practice score, the female gender and those living in an urban region had better practice, but the young age group (0-44 years) was significantly associated with the weak practice.

Conclusion: Although Iraq has adopted a preventive and precautionary plan to control the spread of coronavirus. However, the public's knowledge and attitude toward COVID-19, coupled with the unstable political and security situation, have greatly affected the commitment to preventive measures.
\end{abstract}

Keywords: COVID-19, Knowledge, Attitude, Practice, public, preventive measures, Iraq

\section{Background}

Iraq was among the countries that were early hit by the first wave of the COVID-19 pandemic. Since the appearance of the first case at the end of February 2020, Iraq has taken a series of measures to contain the pandemic [1]. However, the response to the escalating emergencies was not well planned. The decisions made by the Iraqi Higher Committee for Health and National Safety (IHCHNS) did not consider the social and economic situation in Iraq [2]. For example, the imposition of a total

*Correspondence: drsaadalezzi@ gmail.com

${ }^{1}$ Department of Public Health, Faculty of Medicine, Bezmialem Vakif University, Istanbul, Turkey

Full list of author information is available at the end of the article

C The Author(s). 2020 Open Access This article is distributed under the terms of the Creative Commons Attribution 4.0 International License

(http://creativecommons.org/licenses/by/4.0/), which permits unrestricted use, distribution, and reproduction in any medium, provided you give appropriate credit to the original author(s) and the source, provide a link to the Creative Commons license, and indicate if changes were made. The Creative Commons Public Domain Dedication waiver (https://creativecommons.org/publicdomain/zero/1.0/) applies to the data made available in this article, unless otherwise stated. lockdown and its extension several times without providing livelihood alternatives to many groups of society increased the population's suffering and non-compliance [3]. Reports indicate that a small percentage of the population understood the country's serious health situation and respected the lockdown measures. Most of the educational campaigns that were led by the Iraqi government and the non-government organizations (NGOs) at the local and international levels were broken in front of the rock of stubbornness and indifference of many citizens. On the contrary, a high percentage of the population in Iraq followed the statements of the party and religious leaderships that deliberately weakened the central state's decisions and allowed their followers to mix and practice party 
and religious rites despite the spread of the pandemic throughout the country [4].

Unfortunately, people did not realize the seriousness of the situation until the pandemic reached their homes. Lack of health awareness was a prominent characteristic of the Iraqi people. Many infected people have avoided treatment due to the social stigma associated with coronavirus and the prevailing belief that health institutions have become a host for transmission. Others believed that the Coronavirus pandemic was a conspiracy and a political game. Therefore, many cases come late to the hospital with severe respiratory distress [5]. People began to realize how bad the situation was when they or a loved one were brought to a hospital, and they saw patients quickly die every day [6].

Iraq witnessed an alarming increase in the number of cases in the summer, especially in July, August, and September 2020. According to the world meter statistics [Worldometer], the number of confirmed cases in Iraq exceeded 387,121, at a rate of 3,500 new cases per day during the past six weeks [7]. Despite the continuing spread of the pandemic, the IHCHNS decided to ease restrictions on combating the coronavirus by allowing the movement of people between provinces and reopening the borders and crossings in addition to tourism facilities and sporting events [8]. There is no doubt that it is protecting the individuals and preserving society's health among the duties of the central government. Nevertheless, people have an essential role in implementing plans and strategies to prevent diseases and epidemics. This study aimed to assess the knowledge, attitude, and practice (KAP) towards the COVID19 pandemic among the Iraqi people.

\section{Methods}

Study Design and Sample

A cross-sectional study was conducted from 17 July 2020 to 31 July 2020 among Iraq's general population. Given the lockdowns and the restricted movement, data was collected via an online self-reported questionnaire using Google Docs Forms. The researchers distributed the survey link to the participants via Twitter, WhatsApp, and Viber groups.

\section{Inclusion and exclusion criteria}

All Iraqi people living in Iraq understood the questionnaire's content and agreed to participate are included in the study. However, the study excluded the participants from outside Iraq.

\section{Sample size}

The researchers sought to improve the generalizability of the study by maximizing the target sample size. According to world bank data, Iraq's total population was estimated at 39,309.78 in 2019 [9]. The sample size calculator [10] arrived at 1,037 participants, using a margin of error of $\pm 4.0 \%$, a confidence level of $99 \%$, a $50 \%$ response distribution, and 39,309.78 people.

\section{Study tool}

The authors developed the self-reported questionnaire following the guidelines of the Centers for Disease Control and Prevention (CDC) [11]. Moreover, several published articles related to knowledge, attitude, and practice towards the COVID-19 pandemic have been considered [12-23]. Initially, the questionnaire was written in the English language, and then it was translated into the Arabic language. The questionnaire test piloted among 20 respondents not included in the study. Content validation was performed using the content validity rate [24-26]. The online questionnaire's first page contained an assurance of the freedom to participate or withdraw and that all information and opinions submitted would be anonymous and confidential. The questionnaire contains four main sections. The first section is devoted to information on the participants' sociodemographic characteristics, including age, gender, marital status, level of education, employment, place of residency, income level, and self-rated health status. The second section of the questionnaire is dedicated to assessing participants' knowledge of COVID-19. This section contained 20 items focusing on the ways of transmitting the Coronavirus, the clinical symptoms that appear on the infected person, the treatment protocol, and what groups are most at risk of infection, in addition to information on the strategies of isolation, prevention, and control of the pandemic. The third section of the questionnaire included 11 items to assess participants 'attitudes towards COVID-19, using a five-point Likert scale to determine the level of participants' agreement ranging from "1" 'Strongly disagree' to "5" 'Strongly agree'. The fourth section of the questionnaire has six questions recruited to evaluate respondents' practices and behaviors toward COVID19.

\section{Independent variables}

For sociodemographic variables, gender was coded as one for females and zero for males. The age variable was reported in six groups: "<18","18-24", "25-34", "35-44", "45-54", "55-64", "65-74" and ">74" years old. Moreover, the age was categorized into two categorize codded zero for more than 44 years and coded one for 44 years and below. Marital status was captured as binary, and a value of one was used for married and zero for otherwise. Education was categorized and coded into one (high educated) for college/university degree, and postgraduate degree and zero (low educated) for high school or below. Work status categorized and the value of zero given to unemployed and value of one given to employed. Place of residency coded as zero for rural and one for urban. Monthly income (Iraqi Dinar (IQD)1 = United State Dollar (USD) 0.0008 , exchange rate on 10 July 2020) was divided into four categories: <USD 200, USD 200 to <400, USD 400 to1000, and more than USD1000. The self-rated health status was reported in a scale ranged from "very bad" to "very good" in a scale ranged from "1" to "5". Moreover, the self-rated health status was categorized into poor health (very bad, bad, moderate) and good health (good and very good).

\section{Dependent variables}

As with other pandemics, COVID-19 has revealed the Respondents were asked to respond to knowledge items as either true or false, with an additional "do not know" option. Incorrect or uncertain (do not know) responses were given a score of zero, and correct answers were assigned a score of one. The total score for knowledge ranged from zero to 20, with high scores indicating better knowledge of COVID-19. Items were evaluated for internal reliability, using Cronbach's a. Cronbach's alpha coefficient was 0.72 , indicating internal reliability.

In the section on attitudes, scores were calculated based on the respondents' answers to each attitudinal statement, $1=$ 
strongly disagree, 2=disagree, $3=$ undecided, 4=agree, and $5=$ strongly agree. Scores were calculated by averaging respondents' answers to the eleven statements. Total scores ranged from eleven to 55, with high scores indicating positive attitudes. The Likert scales were assessed for internal reliability, using Cronbach's a. Cronbach's alpha coefficient was 0.83, indicating internal reliability. In the section on practices, respondents were asked to respond "yes" or "no" to the items. A score of one was given for answers that reflected good practice, and a score of zero was given for answers that reflected bad practice. The total score ranged from zero to six, with high scores indicating better practices.

Statistical analysis

This study employed primarily univariate and multivariable regression data analyses. Univariate analysis was used to tabulate the frequency of social and demographic statistics. An independent sample t-test and one-way analysis of variance (ANOVA) were used to assess differences in mean values for KAP scores. Because the scores were continuous, the overall mean differences were estimated using a Bartlett test [27]. A multivariable linear regression analysis was performed to identify factors related to knowledge, attitudes, and practice. All analyses were conducted using SPSS version 16 .

\section{Results}

Social and demographic characteristics

A total of 931 participants completed the questionnaire. After excluding 54 respondents who reported living outside Iraq, the final sample consisted of 877 participants. Table 1 shows the social and demographic characteristics of the study participants. More than half of the sample (53.5\%) were between the ages of 18 and 44 . Of the participants, 455 were married (61.9\%), and 422 were unmarried $(48.1 \%)$. More than two-thirds of the sample $(69.7 \%)$ had a college or university degree. The vast majority $(691,78.8 \%)$ of respondent resident in the urban region. In terms of work status, 479 (54.6\%) were unemployed. Respondents were grouped according to monthly income, with $291(33.2 \%)$ in the < USD 400 group, and $586(66.8 \%)$ in the group of USD 400 and more. Of the sample, 360 (41.0\%), 289 $(33.0 \%)$ self-ranked health as good and very good, respectively (Table 1).

Descriptive statistics of KAP scores

As shown in Table 2, the knowledge score $(15.57 \pm 2.46$, range: 0 -20) having an overall $77.85 \%\left(15.57 / 20^{*} 100\right)$ of correct rate was significantly varied across marital status, education, residency, employment, income level and self-ranked health status $(P<0.05)$. The mean attitude score for COVID-19 was 38.88 ( $\mathrm{SD}=3.57$, range: $11-55)$, indicating positive attitudes and significantly varied across income level $(P<0.05)$. The mean score for practices for COVID-19 was 5.13 ( $\mathrm{SD}=1.14$, range: $0-6)$, indicating good practices and significantly varied across residency $(P<0.05)$.

KAP scores by social and demographic characteristics Table 3 presents the mean of KAP scores towards COVID-19 by different social and demographic characteristics in Iraq. Knowledge scores significantly differed across marital status categories, residence places, education level and level of income, and health status. Level of income and residence places are shown as an influential factor in attitude scores and practice scores $(P<0.05)$.

Table 1 Socio demographic factors $(\mathrm{n}=877)$

\begin{tabular}{|c|c|c|c|}
\hline Variabales & Category & $\mathbf{n}$ & $\%$ \\
\hline \multirow[t]{2}{*}{ Gender } & Female & 511 & 58.3 \\
\hline & Male & 366 & 41.7 \\
\hline \multirow[t]{8}{*}{ Age group } & $0-17$ & 67 & 7.6 \\
\hline & $18-24$ & 188 & 21.4 \\
\hline & $25-34$ & 145 & 16.5 \\
\hline & $34-44$ & 137 & 15.6 \\
\hline & $45-54$ & 105 & 12.0 \\
\hline & $55-64$ & 106 & 12.1 \\
\hline & $65-74$ & 72 & 8.2 \\
\hline & $\geq 75$ & 57 & 6.5 \\
\hline \multirow[t]{2}{*}{ Marital status } & $\bar{M}$ Married & 455 & 51.9 \\
\hline & Single & 422 & 48.1 \\
\hline \multirow[t]{2}{*}{ Education } & High education & 611 & 30.3 \\
\hline & Low education & 266 & 69.7 \\
\hline \multirow[t]{2}{*}{ Residency } & Urban & 691 & 78.8 \\
\hline & Rural & 186 & 21.2 \\
\hline \multirow[t]{2}{*}{ Employment } & Unemployed & 479 & 54.6 \\
\hline & Employed & 398 & 45.4 \\
\hline \multirow[t]{4}{*}{ Level of income } & $<\$ 200$ & 73 & 8.3 \\
\hline & $\$ 200-399$ & 218 & 24.9 \\
\hline & $\$ 400-1000$ & 320 & 36.5 \\
\hline & $>\$ 1000$ & 266 & 30.3 \\
\hline \multirow[t]{5}{*}{ Self-ranked health status } & Very poor & 22 & 2.5 \\
\hline & Poor & 47 & 5.4 \\
\hline & Acceptable & 159 & 18.1 \\
\hline & Good & 360 & 41.0 \\
\hline & Very good & 289 & 33.0 \\
\hline
\end{tabular}

Regression results of KAP-related factors

Regression analysis showed that higher educated $(P$-value $=$ $0.000,<0.05)$, urban residents $(P$-value $=0.000,<0.05)$, employed $(P$-value $=0.040,<0.05)$, and having income level of USD 400 or more $(P$-value $=0.000,<0.05)$ were significantly associated with upper knowledge score. Female gender and employed respondents are significantly associated with positive attitude scores, but inversely, respondents with an income of USD 400 or more are significantly associated with a negative attitude. Regarding practice score, the female gender and those living in the urban region had better practice, but the young age group (0-44 years) was significantly associated with weak practice (Table 4).

As presented in Table 5, more than $90 \%$ of the total sample had accurate knowledge related to "washing hands, wearing medical masks, avoiding touching their eyes, nose, and mouth with the unwashed hand ", "clinical symptoms and its importance", "spreads through cough and sneeze by infected people", "elderly people, people with chronic diseases in higher risk" and "the importance of healthy food and drinking water and isolation". However, $34.8 \%$ had a misconception that afebrile patients will not transmit the virus to others. Moreover, 49.8\% have insufficient knowledge about antibiotics' effectiveness, and $38.7 \%$ do not have accurate knowledge about children affected by COVID-19. 31.4\% had difficulty distinguishing coronavirus from influenza. Furthermore, there was a lack of information among the participants regarding pregnant women, and the possibility of infection with Coronavirus $(63.4 \%)$, contact with wild animals (59.4\%), and the importance of wearing a face mask when infected or being close to an infected person (51.4\%). 
More than $95 \%$ of "Maintaining a reasonable distance" and "washing hands" protect individuals and society from coronavirus. $86.2 \%$ reported that they do not believe in staying at home as an effective preventive measure. About $50 \%$ of them thought coronavirus would be controlled, and $54.9 \%$ feel that it was too late for the implication of lockdown at the beginning of the epidemic. Just $50.6 \%$ of them thought the Iraqi government's strict measures were enough to win the battle against coronavirus. Also, $72.3 \%$ of participants thought complying with the National Safety Committee of the Ministry of Health's instructions will prevent the spread of coronavirus. $25.4 \%$ thought the announced number related to infected and dead persons due to coronavirus are exaggerated, $54.9 \%$ of them have a growing concern about the second peak of coronavirus cases (Table 6). In terms of practice towards COVID-19 that are presented in Table 7 in Annex, 15.7\% of participants had attended a social event involving many people, $28.3 \%$ were in a crowded place, $84.5 \%$ did not avoid social behavior such as shake hands or kiss people, $9.1 \%$ did not think seriously about social distancing, $6.6 \%$ were not interested about washing hands after going to a public place, or after blowing your nose, coughing, or sneezing, $11.9 \%$ were not interested about washing things from outside the home.

$\underline{\text { Table } 2 \text { Number of questions, range, scores, and levels of knowledge, attitude, and practice }}$

\begin{tabular}{lcccc}
\hline Variables & Number of questions & Range of score & Total scores (mean \pm SD) & Accuracy rate (\%) \\
\hline Knowledge & 20 & $0-20$ & $15.57 \pm 2.46$ & 77.85 \\
Attitude & 11 & $11-55$ & $38.88 \pm 3.57$ & 70.69 \\
Practice & 6 & $0-6$ & $5.13 \pm 1.14$ & 85.50 \\
\hline
\end{tabular}

Table 3 KAP scores by socio-demographic and economic characteristics

\begin{tabular}{|c|c|c|c|c|c|c|c|c|}
\hline Variables & Categories & Total $(\%)$ & $\begin{array}{l}\text { Knowledge score } \\
(\text { mean } \pm \text { SD) }\end{array}$ & p-value & $\begin{array}{l}\text { Attitude score } \\
(\text { mean } \pm \mathrm{SD})\end{array}$ & p-value & $\begin{array}{l}\text { Practice score } \\
(\text { mean } \pm \mathrm{SD})\end{array}$ & p-value \\
\hline \multirow[t]{2}{*}{ Gender } & Female & $511(58.3)$ & $15.64 \pm 2.35$ & 0.348 & $39.01 \pm 3.57$ & 0.228 & $5.18 \pm 1.13$ & 0.102 \\
\hline & Male & $366(41.7)$ & $15.49 \pm 2.61$ & & $38.71 \pm 3.57$ & & $5.05 \pm 1.14$ & \\
\hline \multirow[t]{2}{*}{ Age } & $0-44$ years & $537(61.2)$ & $15.68 \pm 2.49$ & 0.126 & $38.77 \pm 3.63$ & 0.312 & $5.10 \pm 1.16$ & 0.388 \\
\hline & $>40$ years & $340(38.8)$ & $15.41 \pm 2.42$ & & $39.04 \pm 3.47$ & & $5.17 \pm 1.11$ & \\
\hline \multirow[t]{2}{*}{ Marital status } & Married & $455(51.9)$ & $15.77 \pm 2.45$ & 0.016 & $38.94 \pm 3.49$ & 0.645 & $5.16 \pm 1.13$ & 0.427 \\
\hline & Unmarried & $422(48.1)$ & $15.37 \pm 2.47$ & & $38.83 \pm 3.66$ & & $5.10 \pm 1.15$ & \\
\hline \multirow[t]{2}{*}{ Education } & High education & $611(69.7)$ & $15.94 \pm 2.33$ & 0.000 & $39.87 \pm 3.61$ & 0.733 & $5.17 \pm 1.12$ & 0.117 \\
\hline & Low education & $266(30.3)$ & $14.73 \pm 2.56$ & & $38.94 \pm 3.50$ & & $5.04 \pm 1.18$ & \\
\hline \multirow[t]{2}{*}{ Residency } & Urban & $691(78.8)$ & $15.83 \pm 2.37$ & 0.000 & $38.83 \pm 3.47$ & 0.375 & $5.18 \pm 1.12$ & 0.020 \\
\hline & Rural & $186(21.2)$ & $14.61 \pm 2.62$ & & $39.09 \pm 3.98$ & & $4.96 \pm 1.18$ & \\
\hline \multirow[t]{2}{*}{ Employment } & Employed & $398(45.4)$ & $15.93 \pm 2.30$ & 0.000 & $38.97 \pm 3.44$ & 0.521 & $5.14 \pm 1.12$ & 0.825 \\
\hline & Unemployed & $479(54.6)$ & $15.28 \pm 2.56$ & & $38.81 \pm 3.68$ & & $5.12 \pm 1.15$ & \\
\hline \multirow[t]{2}{*}{ income level } & $\geq$ USD 400 & $586(66.8)$ & $15.90 \pm 2.76$ & 0.000 & $38.72 \pm 3.50$ & 0.053 & $5.16 \pm 1.09$ & 0.329 \\
\hline & $<$ USD 400 & 291(33.2) & $14.91 \pm 2.23$ & & $39.22 \pm 3.70$ & & $5.08 \pm 1.23$ & \\
\hline Self-ranked & Good health & $649(74.0)$ & $15.74 \pm 2.39$ & 0.000 & $38.90 \pm 3.65$ & 0.885 & $5.12 \pm 1.17$ & 0.807 \\
\hline health status & Poor health & $228(26.0)$ & $15.10 \pm 2.60$ & & $38.86 \pm 3.34$ & & $5.14 \pm 1.05$ & \\
\hline
\end{tabular}

Table 4 Regression results of KAP-related factors for COVID-19

\begin{tabular}{|c|c|c|c|c|c|c|c|c|}
\hline \multirow[t]{2}{*}{ Variable } & \multirow[t]{2}{*}{$\mathrm{B}$} & \multirow[t]{2}{*}{ SE } & \multirow[t]{2}{*}{ Beta } & \multirow[t]{2}{*}{$\mathrm{t}$} & \multirow[t]{2}{*}{$P$-value } & $95 \% \mathrm{CI}$ & \multirow[t]{2}{*}{ Tolerance } & \multirow[t]{2}{*}{ VIF } \\
\hline & & & & & & lower-Upper & & \\
\hline \multicolumn{9}{|l|}{ Knowledge $($ Durbin-Watson= 1.865) } \\
\hline Higher educated (VS low educated) & 0.801 & 0.189 & 0.149 & 4.246 & 0.000 & $(0.431,1.171)$ & 0.840 & 1.191 \\
\hline Urban (VS Rural) & 0.830 & 0.203 & 0.138 & 4.089 & 0.000 & $(0.432,1.229)$ & 0.916 & 1.091 \\
\hline Employed (VS unemployed) & 0.285 & 0.168 & 0.058 & 1.696 & 0.040 & $(0.045,0.615)$ & 0.902 & 1.109 \\
\hline$\geq$ USD 400(VS < USD400) & 0.645 & 0.175 & 0.123 & 3.682 & 0.000 & $(0.301,0.988)$ & 0.929 & 1.076 \\
\hline \multicolumn{9}{|l|}{ Attitude (Durbin-Watson= 1.757) } \\
\hline Female (VS male) & 0.447 & 0.263 & 0.062 & 1.696 & 0.040 & $(-0.070,0.963)$ & 0.859 & 1.165 \\
\hline$\geq$ USD $400($ VS < USD400) & -0.559 & 0.259 & -0.047 & -2.161 & 0.031 & $(0.051,1.067)$ & 0.976 & 1.025 \\
\hline Employed (VS unemployed) & 0.395 & 0.263 & 0.055 & 1.498 & 0.013 & $(-1.123,0.912)$ & 0.841 & 1.188 \\
\hline \multicolumn{9}{|l|}{ Practice (Durbin-Watson= 1.754) } \\
\hline Urban (VS rural) & 0.195 & 0.097 & 0.070 & 2.006 & 0.030 & $(0.075,0.315)$ & 0.911 & 1.097 \\
\hline Female (VS Male) & 0.156 & 0.081 & 0.068 & 1.919 & 0.045 & $(0.044,0.386)$ & 0.925 & 1.081 \\
\hline $0-44$ years (vs >44 years) & -1.122 & 0.081 & -0.052 & -1.510 & 0.021 & $(-0.036,0.280)$ & 0.951 & 1.051 \\
\hline
\end{tabular}




\section{Discussion}

To our knowledge, this study is the first national study to explore the knowledge, attitude, and practice of the Iraqis towards the Novel Coronavirus in 2020. The Iraqis scored $77.85 \%$ correct rate of knowledge about the COVID-19 pandemic. The results of this study did not differ from a previous study conducted in Sudan (78.20\%) [12], and higher than rates reported in studies from Egypt and Nigeria (61.6\%) [13], and Bangladesh (48.3\%) [14], however, the rate was lower than the rates recorded in other countries such as China (90.0\%) [15], Cameroon (84.19\%) [16], Saudi Arabi (81.64\%) [17], Malaysia (80.5\%) [18]. Like other studies conducted in Bangladesh [14], China [19], India [20], and Egypt [21], the higher rates of knowledge correlated with a higher level of education among the respondents with a numerical advantage for the youth population. The youth component of high schools and the undergraduate students represent the group that most social media users, which reinforces the hypothesis of having more access to news and information about the COVID-19 pandemic than the elderly. Moreover, the linear regression analysis showed that knowledge was affected by a high percentage of respondents in urban areas. Similar findings were seen in India [20] and Ethiopia [22]. Iraq suffers from a chronic shortage in the supply of electricity and low internet services, especially in rural areas, which significantly contributed to depriving rural residents of regular access to confidential information and the up to date data about the COVOID-19. Furthermore, having a job with a salary is significantly associated with good knowledge about COVID-19. Similar findings were reported in Malaysia [18], Egypt [21]. COVID-19 caused a deterioration in the global economic situation, which negatively affected the population's physical and psychological health state in general $[28,29]$. Coronavirus's impact was more severe on countries that already suffer from an unstable political and economic situation, such as Iraq. There was a limitation to access information among the unemployed and low-income families. Lack of essential services coupled with the deteriorating economic situation in Iraq has made most people interested in securing an income to meet the family's needs rather than improving the knowledge about the Corona epidemic. Similar to findings reported in China [19], Bangladesh [14], Egypt, and Nigeria [13], the vast majority of Iraqis agree that leaving a social distance (95.7\%), washing hands $(97.6 \%)$, and staying at home $(86.2 \%)$ are the best ways to control the epidemic. Unlike previous studies [17, 20, 23], the Iraqis expressed a pessimistic attitude towards the COVID19 epidemic: $45.5 \%$ of respondents believed that the coronavirus pandemic would not be successfully controlled, and $45.4 \%$ of respondents do not have confidence in the Iraqi government's measures to win the battle against the virus. Nevertheless, $72.3 \%$ of the respondents emphasized the need to adhere to the National Safety Committee's instructions at the Ministry of Health to prevent the spread of coronavirus. Although $89.3 \%$ of respondents believed that the complete lockdown was an effective measure to prevent the coronavirus spread, it harmed the family's economic situation, and $49.3 \%$ felt that the implementation was too late. Our survey showed that females were significantly associated with a positive attitude to COVID-19 $(\mathrm{P}=0.040)$ than counterpart men. Our survey results coincide with the results of a study conducted in
Spain [30], which confirmed that women take the epidemic seriously and are more committed to the standards of protection against the coronavirus with more responsibility than men. Not surprisingly, employed respondents $(P=0.013)$ were significantly associated with a positive attitude toward the COVID- pandemic compared to unemployed people. Although this study did not distinguish between government and self or private employment, getting a job with a sufficient income was a challenge in Iraq. The worldwide lockdown led to massive unemployment; therefore, maintaining or getting a job has dramatically mitigated the economic impact of the COVID-19 pandemic and improved the attitude towards pandemic. However, respondents with high incomes had a negative attitude towards Coronavirus, perhaps because they believe that the pandemic would be prolonged, which could reduce their salaries or lose their jobs later. Similar results have been reported in Vietnam. Dang et al. [31] found that the Coronavirus pandemic-related decline in income was at an average of $61.6 \%$ among two-thirds of the study participants and that more than a quarter of them had a salary deficit at forty percent or more. Although the pessimistic attitude prevailed among the respondents, they reacted positively, and the majority of them adhered to the necessary precautions to prevent infection with the COVID-19 virus. More than $84.0 \%$ avoided social events and social behavior, such as shaking hands or kissing. Moreover, over $90.0 \%$ become interested in practicing social distancing and washing hands or things brought from outside the home. On the other hand, $28.3 \%$ of the respondents reported that they went to crowded places and $15.0 \%$ of them attended meetings and social events, explaining the emergence of recurrent infection hotspots in different regions of Iraq, which causes delays or failure of the plans of the competent authorities to combat the coronavirus.

Findings of the regression analysis showed that urban residents $(\mathrm{P}=0.030)$, female sex $(\mathrm{P}=0.045)$, and those aged more than 44 years $(\mathrm{P}=0.021)$ were significantly more likely to practice protective measures against the spread of the coronavirus than their counterparts. Similarly, Yue et al. [19] found that urban area was "associated with a higher practice score" toward COVID-19 than the rural area. Moreover, it is known that urban residents are more concerned with their rights to health services and generally tend to adhere to health instructions compared to rural residents [32]. Brooks DJ and Saad L [33] found that males are less interested in the Coronavirus than females. Therefore, the mortality rate due to Coronavirus was higher among male patients than females. Galasso et al. [34] found that most women considered coronavirus as a severe health problem. Women were keener to know about the Coronavirus pandemic, listen to the instructions, committed to safety measures, and comply with policies than men. Although there is no definitive evidence to exclude a particular age group from infection with Coronavirus, however, published reports from the World Health Organization [35] indicated that young people are at a lower risk of contracting coronavirus based on less severe physical and clinical signs and symptoms associated with COVID-19 than the old age group. Like other studies [17, 35], our study found that young people are less committed to health prevention measures and have less practice. Moreover, older people are 
distinguished by knowledge, wisdom, and responsibility, reflected in better practices than the young age group.

Unfortunately, since 2003, political, financial, and administrative corruption in Iraq has created an environment for a dilapidated health system [36]. Most of the bright medical professionals have emigrated. More than half of already in workplace have the intention to leave on both the graduate and undergraduate levels $[36,37]$, because there is no clear law to protect them from of the recurrent exposure to different types of violation [38]. Faced with all these aforementioned challenges, the central government in Iraq is unable to implement very restrictive measures including complete national lockdown, banning all public gatherings, encouraging social distancing, and the compulsory use of face masks, becomes risky behaviors among the study population

Table 5 Correct responses to knowledge statements regarding COVID-19 (N=877).

\begin{tabular}{|c|c|c|}
\hline No. & Statement & Number (\%) \\
\hline 1 & Corona is a viral disease that spreads from person to person at a distance of up to two meters (6 feet) & $630(71.8)$ \\
\hline 2 & Corona spreads through respiratory droplets that occur when infected people cough and sneeze. & $834(95.1)$ \\
\hline 3 & $\begin{array}{l}\text { Corona infection may occur by touching or kissing the contaminated surfaces or objects and then touching the mouth, } \\
\text { nose, or possibly the eyes. }\end{array}$ & $834(95.1)$ \\
\hline 4 & Eating or touching wild animals can lead to infection with the Coronavirus. & $355(40.5)$ \\
\hline 5 & People infected with COVID-19 cannot transmit the virus to others when a fever is not present. & $572(65.2)$ \\
\hline 6 & The main clinical symptoms of COVID-19 are fever, fatigue, dry cough, myalgia, and shortness of breath. & $849(96.8)$ \\
\hline 7 & Unlike the common cold, congestion, runny nose, and sneezing are less common in people infected with COVID-19. & $602(68.6)$ \\
\hline 8 & Antibiotics are effective in treating COVID-19. & $440(50.2)$ \\
\hline 9 & $\begin{array}{l}\text { Currently, there is no effective cure for COVID-19, but early symptomatic and supportive treatment can help most } \\
\text { patients recover from the diseases. }\end{array}$ & $764(87.1)$ \\
\hline 10 & $\begin{array}{l}\text { The elderly and people who suffer from severe chronic diseases such as heart or lung disease and diabetes have a doubled } \\
\text { risk of developing severe complications from developing a COVID-19. }\end{array}$ & $840(95.8)$ \\
\hline 11 & Pregnant women are more susceptible to infections than non-pregnant women. & $318(36.6)$ \\
\hline 12 & Children are less likely to be infected with COVID- 19 than adults. & $538(61.3)$ \\
\hline 13 & It is not necessary for children or young people to take protective measures against COVID-19 transmission. & $754(86.0)$ \\
\hline 14 & $\begin{array}{l}\text { people must wash their hands with soap and water or use a hand sanitizer containing at least } 60 \% \text { alcohol for at least } 20 \\
\text { seconds. After being in a public place, after nose-blowing, coughing, or sneezing, }\end{array}$ & 788(89.9) \\
\hline 15 & As a precaution, people should avoid touching their eyes, nose, and mouth with unwashed hands. & $858(97.8)$ \\
\hline 16 & Wearing medical masks is very important to prevent corona infection. & $840(95.8)$ \\
\hline 17 & $\begin{array}{l}\text { People should only wear a mask if they are infected with the virus or if they are caring for someone with suspected } \\
\text { COVID-19 infection. }\end{array}$ & $426(48.6)$ \\
\hline 18 & Healthy food and drinking water strengthen the body's immunity and resistance against COVID-19. & $765(87.2)$ \\
\hline 19 & Isolation and treatment of people infected with the COVID-19 are effective ways to reduce the spread of coronavirus. & $855(97.5)$ \\
\hline 20 & $\begin{array}{l}\text { People being in contact with someone infected with COVID-19 should be immediately quarantined, in an appropriate } \\
\text { location, for a general observation period of } 14 \text { days. }\end{array}$ & $797(90.9)$ \\
\hline
\end{tabular}

Table 6 Responses to attitudinal statements regarding COVID-19 (N=877).

\begin{tabular}{|c|c|c|c|c|c|c|}
\hline No. & Statements & $\begin{array}{l}\text { Strongly } \\
\text { agree }\end{array}$ & Agree & $\begin{array}{l}\text { Do not } \\
\text { know }\end{array}$ & Disagree & $\begin{array}{l}\text { Strongly } \\
\text { disagree }\end{array}$ \\
\hline 1 & $\begin{array}{l}\text { Maintaining a reasonable distance from others is very important to } \\
\text { avoid the spread of coronavirus }\end{array}$ & $441(50.3)$ & $398(45.4)$ & $23(2.6)$ & $7(0.8)$ & $8(0.9)$ \\
\hline 2 & $\begin{array}{l}\text { Hand washing is necessary to protect individuals and society from } \\
\text { coronavirus. }\end{array}$ & $496(56.6)$ & $360(41.0)$ & $13(1.5)$ & $1(0.1)$ & $7(0.8)$ \\
\hline 3 & $\begin{array}{l}\text { Staying at home is an effective preventive measure to protect } \\
\text { individuals and society from exposure to CORONA }\end{array}$ & $318(36.3)$ & $438(49.9)$ & $41(4.7)$ & $69(7.9)$ & $11(1.3)$ \\
\hline 4 & I think the Corona epidemic can be successfully controlled. & $94(10.7)$ & $349(39.8)$ & $286(32.6)$ & $116(13.2)$ & $32(3.6)$ \\
\hline 5 & $\begin{array}{l}\text { The strict measures taken by the Iraqi government are sufficient to win } \\
\text { the battle against coronavirus. }\end{array}$ & $90(10.3)$ & $353(40.3)$ & $184(21.0)$ & $160(18.2)$ & $90(10.3)$ \\
\hline 6 & $\begin{array}{l}\text { Complying with the National Safety Committee of the Ministry of } \\
\text { Health instructions will prevent the spread of corona. }\end{array}$ & $162(18.5)$ & $472(53.8)$ & 172(19.6) & $55(6.3)$ & $16(1.8)$ \\
\hline 7 & $\begin{array}{l}\text { The complete lockdown was an effective measure to prevent the } \\
\text { spread of coronavirus, but it negatively affected the family's economic } \\
\text { situation. }\end{array}$ & $334(38.1)$ & $449(51.2)$ & $38(4.3)$ & $48(5.5)$ & $8(0.9)$ \\
\hline 8 & $\begin{array}{l}\text { I think the figures that announced the number of infected people and } \\
\text { the number of deaths due to coronavirus are exaggerated. }\end{array}$ & $60(6.8)$ & $163(18.6)$ & 297(33.9) & $238(27.1)$ & 119(13.6) \\
\hline 9 & $\begin{array}{l}\text { I still think that Corona Virus is a hoax, and there is no need to take } \\
\text { precautions. }\end{array}$ & $7(0.8)$ & $14(1.6)$ & $74(8.4)$ & $311(35.5)$ & $471(53.7)$ \\
\hline 10 & I have a growing concern about the second peak of coronavirus cases & $101(11.5)$ & $381(43.4)$ & $255(29.1)$ & $119(13.6)$ & $21(2.4)$ \\
\hline 11 & $\begin{array}{l}\text { When the lockdown introduced at the beginning of the epidemic, I felt } \\
\text { it was implemented too late }\end{array}$ & $123(14.0)$ & $310(35.3)$ & $178(20.3)$ & 244(27.8) & $22(2.5)$ \\
\hline
\end{tabular}

\section{Conclusion}

In conclusion, this study found that the level of knowledge, attitude, and practice of the Iraqis towards COVID-19 was acceptable. Several factors, including gender, educational level, employment, place of residence, and income, were among KAP determinants towards COVID-19. Likewise, previous studies indicated that the level of KAP is positively and negatively affected by the extent to which the awareness of the population develops and the community's ability to contain diseases and pandemics. In light of the Coronavirus pandemic, many researchers have made valuable efforts to study the KAP of people toward the COVID-19. Often the results were positive, recording reassuring proportions of how well people knew about the new pandemic. Nevertheless, the spread of the pandemic at such a rapid speed in different and distant societies raises questions about the extent to which people are serious about adhering to health institutions' instructions. 
Table 7 Practices related to COVID-19 (N=877).

\begin{tabular}{|c|c|c|c|}
\hline No. & Statement & Yes & No \\
\hline 1 & $\begin{array}{l}\text { Have you recently attended a social event (such as a wedding party, funeral parlor, etc.) involving many } \\
\text { people? }\end{array}$ & $138(15.7)$ & $739(84.3)$ \\
\hline 2 & Have you recently been in a crowded place? & $248(28.3)$ & $629(71.7)$ \\
\hline 3 & $\begin{array}{l}\text { Have you recently avoided shaking hands or kissing or any social behavior that calls for meeting and } \\
\text { closeness? }\end{array}$ & $136(15.5)$ & $741(84.5)$ \\
\hline 4 & $\begin{array}{l}\text { Have you seriously thought about practicing social distancing and leaving a distance when talking to } \\
\text { people? }\end{array}$ & $797(90.9)$ & $80(9.1)$ \\
\hline 5 & $\begin{array}{l}\text { Have you recently become more interested in washing your hands with soap and water frequently for at } \\
\text { least } 20 \text { seconds, especially after going to a public place or after blowing your nose, coughing, or sneezing? }\end{array}$ & $819(93.4)$ & $58(6.6)$ \\
\hline 6 & $\begin{array}{l}\text { Have you recently become more interested in washing things that you bring from outside the home, } \\
\text { including fruits and vegetables? }\end{array}$ & $773(88.1)$ & 104(11.9) \\
\hline
\end{tabular}

\section{Abbreviation}

COVID-19: Coronavirus; IHCHNS: Iraqi Higher Committee for Health and National Safety; NGOs: Non-Government Organizations; CDC: Centers for Disease Control and Prevention; KAP: Knowledge, Attitude, Practice; IQD: Iraqi Dinar; USD: United State Dollar

\section{Declaration}

\section{Acknowledgment}

We would like to thank Mr. Anmar Shukur Mahmood for his great efforts in helping to prepare the questionnaires and the necessary links and distribution through the social networking sites. We also extend our thanks to all respondents to the survey during the Coronavirus pandemic.

\section{Funding}

The authors received no financial support for their research, authorship, and/or publication of this article.

\section{Availability of data and materials}

Data will be available by emailing drsaadalezzi@gmail.com

\section{Authors' contributions}

Saad Ahmed Ali Jadoo (SAAJ) is the principal investigator of this manuscript (Original manuscript) who designed the study and coordinated all aspects of the research including the study design, analysis, and interpretation of data, drafting the work, writing the manuscript, and reviewed and approved the manuscript. SAAJ, MAMA, SMY contributed to the study concept, design, writing, reviewing, editing, and approving the manuscript in its final form. MWA contributed to data collection. RAA, and AKA contributed to drafting the manuscript. All authors have read and approved the final manuscript.

\section{Ethics approval and consent to participate}

We conducted the research following the Declaration of Helsinki, and the protocol was approved by the Ethics Committee of the Scientific Issues and Postgraduate Studies Unit (PSU), College of Medicine, University of Anbar (Ref: SR/368 at 19-July-2020); the Ethics Committee of the College of Medicine, Diyala University (Ref: 1250 at 15-July-2020); National Cancer Institute, Misrata, Libya (Ref: 0000 at 91-August-2020). Moreover, web-based informed consent obtained from each participant after explanation of the study objectives and the guarantee of secrecy.

\section{Consent for publication}

Not applicable

\section{Competing interest}

The authors declare that they have no competing interests.

\section{Open Access}

This article is distributed under the terms of the Creative Commons $\begin{array}{llll}\text { Attribution } & 4.0 & \text { International License }\end{array}$ (http://creativecommons.org/licenses/by/4.0/), which permits unrestricted use, distribution, and reproduction in any medium, provided you give appropriate credit to the original author(s) and the source, provide a link to the Creative Commons license, and indicate if changes were made. The Creative Commons Public Domain Dedication waiver (http://creativecommons.org/publicdomain/zero/1.0/) applies to the data made available in this article, unless otherwise stated.

\section{Author details}

${ }^{1}$ Department of Public Health, Faculty of Medicine, Bezmialem Vakif University, Istanbul, Turkey. ${ }^{2}$ Department of Internal Medicine, Faculty of Medicine, Diyala University, Iraq. ${ }^{3}$ Department of Anatomy, Molecular Genetics, Faculty of Medicine, University of Diyala, Diyala, Iraq. ${ }^{4}$ Ddepartment of family and community medicine, Faculty of Medicine, Anbar University, Anbar, Iraq. ${ }^{5}$ Department of Physiology, Faculty of Medicine, Diyala University, Diyala, Iraq. ${ }^{6}$ Department of Biology, Faculty of Education for Pure Science, Diyala University, Iraq.

\section{Article Info}

Received: 13 August 2020

Accepted: 01 October 2020

Published: 19 December 2020

\section{References}

1. World Health Organization, Early COVID-19 preparation saved lives in Iraq. Available from: http://www.emro.who.int/irq/iraqnews/early-covid-19-preparation-saved-lives-in-iraq.html [Accessed on 25 October 2020]

2. Government of Iraq, Covid-19: Higher Committee for Health and National Safety announces new measures. Available from: https://gds.gov.iq/covid-19-higher-committee-for-health-andnational-safety-announces-new-measures/ [Accessed on 25 October 2020]

3. EPIC, Iraq's health system at risk: the struggle to fight covid-19 and save lives, June 25, 2020. Available from: https://enablingpeace.org/iraqs-health-system-at-risk/ [Accessed on 25 October 2020]

4. Al-Dahhan WH, Al-Mashhadani MH, Raheem R, Yousif E. Iraq faces the COVID-19 with limited health capabilities and major medical challenges. Bionatura 2020;5(3):1271-1274. 10.21931/RB/2020.05.03.19

5. Rubin AJ. Stigma hampers Iraqi efforts to fight the coronavirus The New York Times, April 14, 2020. Available from: https://www.nytimes.com/2020/04/14/world/middleeast/iraqcoronavirus-stigma-quarantine.html [Accessed on 25 October 2020]

6. Medicine Sans Fronters (MSF). COVID-19 outbreak in Baghdad is "very alarming", 24 Sep 2020. Available from: 
https://www.msf.org/covid-19-outbreak-baghdad-iraq-veryalarming [Accessed on 25 October 2020]. $\begin{array}{llll}\text { 7. Worldometer, Iraq. } & \text { Available } & \text { from: } \\ \text { https://www.worldometers.info/coronavirus/country/iraq/ } & \end{array}$ [Accessed on 06 October 2020]

8. Gardaworld. Iraqi authorities allow ease of COVID-19 restrictions on September 8; follow authority directives, 08 Sep 2020 Available from: https://www.garda.com/crisis24/newsalerts/377066/iraq-authorities-ease-covid-19-restrictionsseptember-8-update-50 [Accessed on 06-October 2020]

9. The world bank, data, Population, total. Availabe at: https://data.worldbank.org/indicator/SP.POP.TOTL [Accessed 04 on July 2020]

10. Raosoft, sample size calculator. Available from: http://www.raosoft.com/samplesize.html?nosurvey [Accessed 06October 2020]

11. CDC. Centers for Disease Control and Prevention: Coronavirus (COVID-19) 2020. Available online at: https://www.cdc.gov/coronavirus/2019-nCoV/index.html [Accessed on 1 July 2020].

12. 12. Hezima A, Aljafari A, Aljafari A, Mohammad A, Adel I. Knowledge, attitudes, and practices of Sudanese residents towards COVID-19. East Mediterr Health J. 2020 Jun 24;26(6):646-651. https://doi.org/10.26719/emhj.20.076.

13. Hager E, Odetokun IA, Bolarinwa O, Zainab A, Okechukwu O, Al-Mustapha AI. Knowledge, attitude, and perceptions towards the 2019 coronavirus pandemic: A bi-national survey in Africa. PLOS ONE 2020; 15(7): e0236918. https://doi.org/10.1371/journal.pone.0236918

14. Ferdous MZ, Islam MS, Sikder MT, Mosaddek ASM, ZegarraValdivia JA, Gozal D.Knowledge, attitude, and practice regarding COVID-19 outbreak in Bangladesh: An online-based crosssectional study. PLOS ONE2020; 15(10): e0239254. https://doi.org/10.1371/journal.pone.0239254

15. Zhong BL, Luo W, Li HM, Zhang QQ, Liu XG, Li WT, Li Y. Knowledge, attitudes, and practices towards COVID-19 among Chinese residents during the rapid rise period of the COVID-19 outbreak: a quick online cross-sectional survey. Int J Biol Sci. 2020 Mar 15;16(10):1745-1752. https://doi.org/10.7150/ijbs.45221

16. Ngwewondo A, Nkengazong L, Ambe LA, Ebogo JT, Mba FM, Goni HO, Nyunaï N, Ngonde MC, Oyono JE. Knowledge, attitudes, practices of/towards COVID 19 preventive measures and symptoms: A cross-sectional study during the exponential rise of the outbreak in Cameroon. PLoS Negl Trop Dis. 2020 Sep 4;14(9): e0008700. https://doi.org/10.1371/journal.pntd.0008700

17. Al-Hanawi MK, Angawi K, Alshareef N, Qattan AMN, Helmy HZ, Abudawood Y, Alqurashi M, Kattan WM, Kadasah NA, Chirwa GC, Alsharqi O. Knowledge, attitude and practice toward COVID-19 among the public in the kingdom of saudi arabia: a cross-sectional study. Front Public Health. 2020 May 27; 8:217. https://doi.org/10.3389/fpubh.2020.00217

18. Azlan AA, Hamzah MR, Sern TJ, Ayub SH, Mohamad E. Public knowledge, attitudes and practices towards COVID-19: A crosssectional study in Malaysia. PLoS One. 2020 May 21;15(5): e0233668. https://doi.org/10.1371/journal.pone.0233668

19. Yue S, Zhang J, Cao M, Chen B. Knowledge, attitudes and practices of COVID-19 among urban and rural residents in china: a cross-sectional study. J Community Health. 2020 Aug 5:1-6. https://doi.org/10.1007/s10900-020-00877-x

20. Pal R, Yadav U, Grover S, Saboo B, Verma A, Bhadada SK. Knowledge, attitudes and practices towards COVID-19 among young adults with Type 1 diabetes mellitus amid the nationwide lockdown in India: A cross-sectional survey. Diabetes Res Clin Pract 2020; 166:108344. https://doi.org/10.1016/j.diabres.2020.108344

21. Abdelhafiz AS, Mohammed Z, Ibrahim ME, Ziady HH, Alorabi M, Ayyad M, Sultan EA. Knowledge, perceptions, and attitude of egyptians towards the novel coronavirus disease (COVID-19). J Community Health. $2020 \quad$ Oct;45(5):881-890 https://doi.org/10.1007/s10900-020-00827-7

22. Akalu Y, Ayelign B, Molla MD. Knowledge, attitude and practice towards COVID-19 among chronic disease patients at Addis Zemen hospital, northwest Ethiopia. Infect Drug Resist. 2020; 13:1949-1960. https://doi.org/10.2147/IDR.S258736

23. Hussain A, Garima T, Singh B, Ram R, Tripti R. Knowledge, attitudes, and practices towards COVID-19 among Nepalese
Residents: A quick online cross-sectional survey. AJMS 2020;11(3):6-1 https://doi.org/10.3126/ajms.v11i3.28485

24. Ali Jadoo SA, Aljunid SM, Seher Nur Sulku, Al-Dubai SAR, Wan Puteh SE, Ahmed Z, Abdul Manaf MR, Sulong SB, Nur AM. Health system reform from the people's point of view: development of reliable and valid questionnaire. Malaysian Journal of Public Health Medicine 2013;13(2):65-76.

25. Al-Samarrai M, Al-Rawi R, Yaseen S, Ali Jadoo S. Knowledge, attitude, and practice of mothers about complementary feeding for infants aged 6-12 months in Anbar Province, Iraq. Journal of Ideas in Health 2020; 3(1):125-9. https://doi.org/10.47108/jidhealth.Vol3.Iss1.17

26. Ali Jadoo SA, Sulku SN, Aljunid SM, Dastan I. Validity and reliability analysis of knowledge of, attitude toward and practice of a case-mix questionnaire among Turkish healthcare providers. JHEOR. 2014;2(1):96-107.

27. Wetzels R, Grasman RP, Wagenmakers E-J. A default Bayesian hypothesis test for ANOVA designs. Am Statist. (2012) 66:104 11 https://doi.org/10.1080/00031305.2012.695956

28. Desai M, Khan A, Kulkarni R, Hegde B. The psychologica impact of COVID-19 and the subsequent social isolation on the general population of Karnataka, India. Journal of Ideas in Health.2020;3(Special1):190-5 https://doi.org/10.47108/jidhealth.Vol3.IssSpecial1.51

29. Ali Jadoo SA. COVID -19 pandemic is a worldwide typical biopsychosocial crisis. Journal of Ideas in Health.2020;3(2):152-4. https://doi.org/10.47108/jidhealth.Vol3.Iss2.58

30. de la Vega R, Ruíz-Barquín R, Boros S, Szabo A. Could attitudes toward COVID-19 in Spain render men more vulnerable than women? Global Public Health. 2020 Sep;15(9):1278-1291. https://doi.org/10.1080/17441692.2020.1791212

31. Dang AK, Le XTT, Le HT, Tran BX, Do TTT, Phan HTB, et al. Evidence of COVID-19 impacts on occupations during the first Vietnamese national lockdown. Annals of Global Health. 2020;86(1):112. http://doi.org/10.5334/aogh.2976

32. Ali Jadoo SA, Yaseen S, Al-Samarrai M, Mahmood A. Patien satisfaction in outpatient medical care: the case of Iraq. Journal of Ideas in Health 2020;3(2):176-182. https://doi.org/10.47108/jidhealth.Vol3.Iss2.44

33. Deborah Jordan Brooks, Lydia Saad. Double Whammy: Why the underrepresentation of women among workplace and political decision-makers matters in pandemic times. Politics \& Gender, 2020; 1 https://doi.org/10.1017/S1743923X20000628

34. Galasso V, Pons V, Profeta P, Becher M, Brouard S, Foucault M. Gender differences in COVID-19 attitudes and behavior: Panel evidence from eight countries. Proceedings of the National Academy of Sciences 2020; 117 (44): 27285-27291; DOI: 10.1073/pnas.2012520117

35. WHO (2020), Statement - Older people are at highest risk from COVID-19, but all must act to prevent community spread, http://www.euro.who.int/en/health-topics/healthemergencies/coronavirus-covid-19/statements/statement-olderpeople-are-at-highest-risk-from-covid-19,-but-all-must-act-toprevent-community-spread.

36. Ali Jadoo SA, Aljunid SM, Dastan I, Tawfeeq RS, Mustafa MA Ganasegeran K, Aldubai SA. Job satisfaction and turnover intention among Iraqi doctors-a descriptive cross-sectional multicenter study. Hum Resour Health2015; 13:21. https://doi.org/10.1186/s12960-015-0014-6

37. Al-Samarrai MA, Ali Jadoo SA. Iraqi medical students are still planning to leave after graduation. Journal of Ideas in Health 2018;1(1):23-8. https://doi.org/10.47108/jidhealth.Vol1.Iss1.5

38. Ali Jadoo SA, Torun P, Dastan I, Al-Samarrai M. Impact of conflict related and workplace related violence on job satisfaction among physicians from Iraq - a descriptive cross-sectional multicentre study. Journal of Ideas in Health 2018;1(1):14-2. https://doi.org/10.47108/jidhealth.Vol1.Iss1.4 